\title{
Effect of Roasting Regime on Phytochemical Properties of Senna occidentalis Seeds
}

\author{
Abiodun Adekunle Olapade ${ }^{\mathrm{a}^{*}}$ and Oreofeoluwatomi Adedamola Ajayi ${ }^{\mathrm{a}}$ \\ ${ }^{\text {a }}$ Department of Food Technology, University of Ibadan, Ibadan, Oyo State, Nigeria \\ ${ }^{*}$ Corresponding author \\ aaolapade@yahoo.com \\ TEL: +234-70-605-286-93
}

Received: 30 April 2016; Published online: 18 October 2016

\begin{abstract}
Senna occidentalis seeds were roasted at varying temperatures of 190,210 and $230{ }^{\circ} \mathrm{C}$ each for 10 , 15 and $20 \mathrm{~min}$. Phytochemicals of the roasted seeds were determined using standard methods. The phytochemicals analysed were tannins, saponins, flavonoids, alkaloids, glycosides, oxalate and phenolics. Phytochemicals are compounds hypothesized for much of the disease-protection provided by diets high in fruits, vegetables, legumes, cereals and plant-based beverages. This study has clearly shown that roasting time and temperature have significant effects on the seed parameters analyzed. There was an increase in tannin, alkaloid, saponin and phenolic contents and a decrease in the contents of flavonoids and oxalates.
\end{abstract}

Keywords: Coffee substitute; Time-temperature combination; Significant difference; Phytochemical properties

\section{Introduction}

The term 'substitute' refers to goods that are more or less interchangeable to a consumer (Encarta, 2009), such that one may be conveniently used in place of the other. "Coffee senna", botanically classified as both Senna occidentalis and Cassia occidentalis, seeds are chief substitutes of coffee and are thus sometimes roasted and made into a "coffee-like beverage" (Vashishtha, John, \& Kumar, 2009; Abubakar \& Sule, 2010; Sharma et al., 2013; Shittu et al., 2014; Teles, Fock, \& Gomiak, 2015). Roasting is a primary preparation stage for coffee and coffee substitutes (Belitz, Grosch, \& Schieberle, 2009). The effects of roasting include microbial inactivation, chemical damage, enzyme inactivation and physical changes (Lewis, 2006). Thus it alters sensory properties; improving palatability, extending the variety of tastes, aromas and textures in foods produced from similar raw materials.

Senna occidentalis seeds range in colour from greenish-brown to dark brown with a smooth surface that may have small bright coloured bands on the outer surface (Anonymous, 2012; Oshoke \& Akinyemi, 2015). The seed was wrongly identified as $C$. sieberiana in earlier reports where physical and chemical properties of raw seed (Olapade, Ajayi, \& Ajayi, 2014) and also changes in some physicochemical properties of the seed during roasting were studied (Olapade, Akinoso, \& Oduwaye, 2012). No study has been done to date to evaluate the effect of roasting on phytochemical properties of the seed.

'Phytochemicals' are chemical substances, constitutive metabolites essential for survival, proper functioning, and protection against predators, amongst others (Molyneux, Lee, Gardner, Panter, \& James, 2007). Although their inherent activities can have decidedly ad- 
verse effects on other organisms, especially animals, they confer good qualities beneficial to humans and are compounds hypothesized for much of the disease-protection provided by diets high in fruits, vegetables, legumes, cereals and plantbased beverages (Tyagi, Singh, Sharma, \& Aggarwal, 2010; Teles et al., 2015). Phytochemicals analysed were tannin, saponin, flavonoid, alkaloid, glycoside, oxalate and phenolics.

Tannins affect the availability of amino acids and the utilization of protein. They inhibit the activities of digestive enzymes and are known for their ability to reduce digestibility of food proteins because they form insoluble complexes with proteins (Morrow, 1991; Griffiths \& Moseley, 1980; Sharma \& Sehgal, 1992; Ogunlade, Ilugbiyin, \& Osasona, 2011). Saponins exhibit anti-fungal, anti-inflammatory, fungistatic, haemolytic, molluscidal and foaming activities and influence the body's immune system; lowering cholesterol levels and protecting against cancers (Shi et al., 2004). Of interest in beverages are the aesthetic appeal and a desirable mouth-feel. These are favoured by the presence of foam in or on the cup of the beverage. Saponins have foam causing properties and as such it is expected that they not only enhance health but stimulate the appeal to consume coffee substitutes.

Alkaloids and their derivatives have very important biological functions as analgesics and antispasmodics, and possess bactericidal activities (Hussain et al., 2011). Cyanogenic glycoside on hydrolysis yields toxic hydrocyanide acid (HCN). The cyanide ions inhibit several enzyme systems and depress growth through interference with certain essential amino acids and utilization of associated nutrients (Audu, Aremu, \& Lajide, 2013). Oxalates are known to adversely affect mineral availability in foods. It was reported that a high intake of oxalates could result in gastro-intestinal irritation, blocking of the renal tubes, muscular weakness or paralysis (Innocentia, Ojotu, \& Emmanuel, 2014). Phenols and phenolics compounds are greatly used in skin infections and other wound treatments, and also for healing and as antimicrobial agents (Hussain et al., 2011).

The aim of this research was to study the effect of roasting at various time-temperature combinations on the phytochemical properties of Cassia occidentalis as a coffee substitute.

\section{Materials and Methods}

\subsection{Materials}

The seeds used for this project were obtained from a settlement; Ajibode in Ibadan, Oyo state.

\subsection{Sample preparation}

The pods containing the seeds were opened and the seeds within removed. The seeds obtained were carefully sorted to make sure only good seeds were used. Seeds obtained were stored in polyethylene (PET) bottles before and after being roasted. Roasting was done using a gas oven at the Human Nutrition Department of the University and was carried out at 190, 210 and 230 ${ }^{\circ} \mathrm{C}$ each for 10,15 and 20 minutes. Each experiment of $100 \mathrm{~g}$ seed was done in triplicate. The roasted seeds were cooled, coded, packed and later milled to powder. The raw seeds of the plant are shown in Plate 1. Samples were thoroughly mixed prior to sampling for analysis. The milled samples were stored in a low density polyethylene bag and polyethylene bottles in a cool and dry place to protect it from insect, dust, moisture gain and loss of flavour.

\subsection{Phytochemical Analyses}

All the determinations described below were run in triplicates.

\section{Tannin content determination}

Tannin content was determined as reported by Sharma and Sehgal (1992). 0.5 gram of sample was measured into a $50 \mathrm{ml}$ beaker and $10 \mathrm{ml}$ of water was added. The mixture was shaken, covered and left to stand for 1 hour. One $\mathrm{ml}$ of extract was transferred into a flask. Then, $5 \mathrm{ml}$ distilled water and 2 drops $5 \% \mathrm{FeCl}_{3}$ aqueous solution were added and the solution was shaken to mix it properly. Thereafter, 4 drops of potassium ferrocyanide was added, and coloration developed. Preparations for a standard curve were made with 0.5 gram of tannic acid in $50 \mathrm{ml}$ of 
water. Aliquots of $0.0 \mathrm{ml}, 0.1 \mathrm{ml}, 0.2 \mathrm{ml}$, up to $1.0 \mathrm{ml}$ were taken and each was made up to $10 \mathrm{ml}$ with distilled water. The absorbance of sample and standard tannic acid solutions were read after colour development on a spectrophotometer at a wavelength of $620 \mathrm{~nm}$ and calculations were made.

\section{Saponin content determination}

The spectrophotometric method (Hussain et al., 2011) was used for saponin analysis. One gram sample was weighed into a beaker and $10 \mathrm{ml}$ petroleum ether was added. The mixture was shaken to ensure uniform mixing. Thereafter, supernatant was decanted and then evaporated to dryness. $6 \mathrm{ml}$ of $80 \%$ ethanol was added to dried filtrate and swirled. From this, a $2 \mathrm{ml}$ aliquot was transferred into test tube. $2 \mathrm{ml}$ of $5 \% \mathrm{FeCl}_{3}$ aqueous solution was added and the preparation was left to stand for 30 minutes meanwhile, colour developed. 0 to $10 \mathrm{ppm}$ standard saponin solutions were prepared from saponin stock solution. The standard solutions were treated similarly with $2 \mathrm{ml}$ of $5 \% \mathrm{FeCl}_{3}$ aqueous solution. The absorbance of the sample as well as standard saponin solutions were read after colour development on spectrophotometer at a wavelength of $550 \mathrm{~nm}$.

\section{Flavonoids content determination}

Spectrophotometric method in Kathirvel and Sujatha (2012) was adopted and adapted as follows. 0.50 gram of sample was weighed. To this, $10 \mathrm{ml}$ of ethanol was added and the mixture was left for 15 minutes. One $\mathrm{ml}$ of solution was transferred and $9 \mathrm{ml}$ of distilled water added. Upon agitation, $1 \mathrm{ml}$ was extracted. $6.1 \mathrm{ml}$ distilled water and $0.3 \mathrm{ml}$ of $5 \% \mathrm{NaNO}_{3}$ aqueous solution was added and left for 6 minutes. Thereafter, $0.6 \mathrm{ml}$ $5 \% \mathrm{AlCl}_{3}$ aqueous solution was added in and it was again left for 5 minutes. Finally, $2 \mathrm{ml}$ of $5 \%$ $\mathrm{NaOH}$ was added and sample absorbance read at $510 \mathrm{~nm}$.

\section{Alkaloids content determination}

Determination of the alkaloid content was done by the alkaline precipitation method described by
Harborne (1998) with modification. Five gram of the sample was dispersed in $20 \%$ acetic acid solution in ethanol to form a ratio of 2:8 (20\%). The mixture was allowed to stand for 4 hours at $28{ }^{\circ} \mathrm{C}$ with lid and was later filtered. The filtrate was concentrated to one quarter of its original volume by evaporation and treated with drop-wise addition of conc. aqueous $\mathrm{NH}_{4} \mathrm{OH}$ until the alkaloid was precipitated. The precipitated alkaloid was received in a weighed filter paper, washed with $1 \%$ ammonia solution and dried in the oven at $80{ }^{\circ} \mathrm{C}$. Alkaloid content was calculated and expressed as a percentage of the weight of sample analyzed (Hussain et al., 2011).

\section{Glycoside content determination}

To one gram of sample, $25 \mathrm{ml}$ of $15 \%$ lead acetate aqueous solution was added and the mixture was filtered. Two $\mathrm{ml}$ of chloroform was added to the filtrate and shaken vigorously. Clear fluid, i.e. lower layer, was collected and evaporated to dryness. Three $\mathrm{ml}$ of glacial acetic acid, $0.1 \mathrm{ml}$ of $5 \% \mathrm{FeCl}_{3}$ aqueous solution and $0.25 \mathrm{ml}$ of conc. $\mathrm{H}_{2} \mathrm{SO}_{4}$ were added and the mixture thoroughly shaken. It was then allowed to stand in dark for 2 hours after which absorbance was read at 530 nm.

\section{Oxalates content determination}

A 0.5 gram portion of sample was weighed. 10 $\mathrm{ml}$ distilled water and $1 \mathrm{ml}$ conc. $\mathrm{H}_{2} \mathrm{SO}_{4}$ were added. The solution was left to stand overnight. Thereafter, $39 \mathrm{ml}$ distilled water was added. An aliquot of $5 \mathrm{ml}$ was taken. This was titrated against $0.05 \mathrm{M}$ standardized aqueous $\mathrm{KMnO}_{4}$ solution till pink colour, which persists for $30 \mathrm{sec}-$ onds, was obtained.

\section{Phenolics content determination}

The sample $(0.5 \mathrm{~g})$ was weighed into a conical flask and $10 \mathrm{ml}$ ethanol was added. One $\mathrm{ml}$ of extract was taken and to it was added $9 \mathrm{ml}$ of distilled water. A one $\mathrm{ml}$ aliquot was taken and 4.5 $\mathrm{ml}$ of Folin-Ciocalteu's reagent was added. Two $\mathrm{ml}$ of $7.5 \% \mathrm{Na}_{2} \mathrm{CO}_{3}$ aqueous solution was added and the mixture agitated. Solution absorbance was read at $610 \mathrm{~nm}$. 


\subsection{Phenolics content determination}

Results of each experiment were analysed to assess significant differences between raw and roasted samples' parameters at a significance level of $\mathrm{p}>0.05$. All data was collated on $\mathrm{Mi}$ crosoft Excel sheet, analyzed using SPSS 20.0 and presented as mean \pm standard deviation (Arunkumar \& Muthuselvam, 2009).

\section{Results and Discussion}

\subsection{Phytochemical content}

The results of the phytochemical content of raw seed and seed roasted at $190{ }^{\circ} \mathrm{C}, 210{ }^{\circ} \mathrm{C}$ and 230 ${ }^{\circ} \mathrm{C}$ each at 10,15 and 20 minutes respectively are presented in Table 1. Tannin content ranged from $0.13 \%$ for roasting condition $190{ }^{\circ} \mathrm{C} / 20$ $\min$ to $0.25 \%$ in $230{ }^{\circ} \mathrm{C} / 20 \mathrm{~min}$. Compared to raw sample, tannin content in samples undergoing roasting at $190{ }^{\circ} \mathrm{C} / 15 \mathrm{~min}$ and $190{ }^{\circ} \mathrm{C} / 20$ min was reduced, while it was unchanged for 210 ${ }^{\circ} \mathrm{C} / 10 \mathrm{~min}$ and $210{ }^{\circ} \mathrm{C} / 15 \mathrm{~min}$, but it increased for $190{ }^{\circ} \mathrm{C} / 10 \mathrm{~min}, 210^{\circ} \mathrm{C} / 20 \mathrm{~min}$ and all roasted samples at $230{ }^{\circ} \mathrm{C}$. With a roasting time of 15 min, the tannin content increased with increase in temperature. Tannin contents of both raw and roasted seeds of coffee senna were at least $90 \%$ lower than the 2.27 and $2.73 \%$ of raw and roasted seeds of coffee-like baobab (Innocentia et al., 2014). The tannin content of the water extract of the raw sample $(0.16 \%)$ was much lower than those of chloroform, methanol and petroleum ether extracts of raw Cassia occidentalis reported in Kathirvel and Sujatha (2012). With respect to other plants, the tannin content of samples undergoing roasting at $210{ }^{\circ} \mathrm{C} / 20 \mathrm{~min}$ was comparable to that of Sesbania pachycarpa (Proll, Petzke, Ezeagu, \& Metges, 1998) and watermelon seed kernel flour (El-Adawy \& Taha, 2001); at $230{ }^{\circ} \mathrm{C} / 15$ min was comparable to that of fluted pumpkin leaf extract (Nworgu, Ogungbenro, \& Solesi, 2007) and Enterolobium cyclocarpium (Proll et al., 1998); and at $230{ }^{\circ} \mathrm{C} / 20$ min was comparable to Prosopis Africana (Proll et al., 1998). All the roasted samples had lower tannin content than $0.32 \%$ of protein isolate of Jatropha curcas (Makkar, Francis, \& Becker, 2008); $0.38 \%$ of Lonchocarpus sericeus (Proll et al., 1998); $0.448 \%$ and $0.234 \%$ of raw and processed mango seed flour (Arogba, 1997); $0.48 \%$ of paprika seed and $0.69 \%$ of Pterocarpus osun (Proll et al., 1998) but higher than $0.12 \%$ and $0.127 \%$ in Adansonia digitate and $100 \%$ maize ogi flour respectively (Proll et al., 1998; Enujiugha, 2006).

The saponin content of raw and roasted samples ranged from $0.012 \%$ to $0.019 \%$ as revealed in Table 1. Raw samples had a saponin content of $0.013 \%$. The presence of saponin in coffee senna contradicts results of Veerachari and Bopaiah (2012), Mensah, Okoli, Turay, and Ogie-Odia (2009) and Olapade et al. (2014) who found no saponin in the seed. Of the roasted samples, only sample $190{ }^{\circ} \mathrm{C} / 20 \mathrm{mins}$ had a percentage of saponin content lower than that in the raw sample; though not significantly lower. According to Akinmutimi (2006) about $44.25 \%$ reduction in saponin content occurred in jack beans cooked for 60 minutes; more than in those cooked for 20 and 40 minutes. A similar trend was observed with the roasted Cassia occidentalis seeds, where the saponin content was observed to reduce with an increase in duration of roasting from 10 to 15 minutes and then to 20 mins at $190{ }^{\circ} \mathrm{C}$ and $210{ }^{\circ} \mathrm{C}$. The saponin contents observed in raw and roasted coffee senna seeds were lower than the values reported for raw $(7.20 \%)$ and fermented (6.71 \%) Cassia tora (Adamu, Ushie, \& Elisha, 2013) and for raw (3.26\%) and roasted $(7.23 \%)$ coffee-like baobab seed (Innocentia et al., 2014). The values were also lower than the ones stated for grain legumes (Khokhar \& Apenten, 2003), raw S. obtusifolia (Ingweye, Kalio, Ubua, \& Umoren, 2010) and all medicinal plants investigated by Edeoga, Okwu, and Mbaebie (2005) and by Aliyu, Musa, Oshanimi, Ibrahim, and Oyewale (2008). Flavonoids are beneficial phytochemicals. All the seeds; raw and roasted were found to contain flavonoids. All roasted samples except the ones roasted at $190{ }^{\circ} \mathrm{C}$ for 10 minutes had lower quantities of flavonoid when compared to raw seed. Roasting for more than 10 minutes at $190{ }^{\circ} \mathrm{C}$ and roasting at temperatures above $190{ }^{\circ} \mathrm{C}$ caused a significant reduction in flavonoids' content by as much as $87.1 \%$. Flavonoids' content reduced with in- 
Roasting of Senna occidentalis seeds $\mid 207$

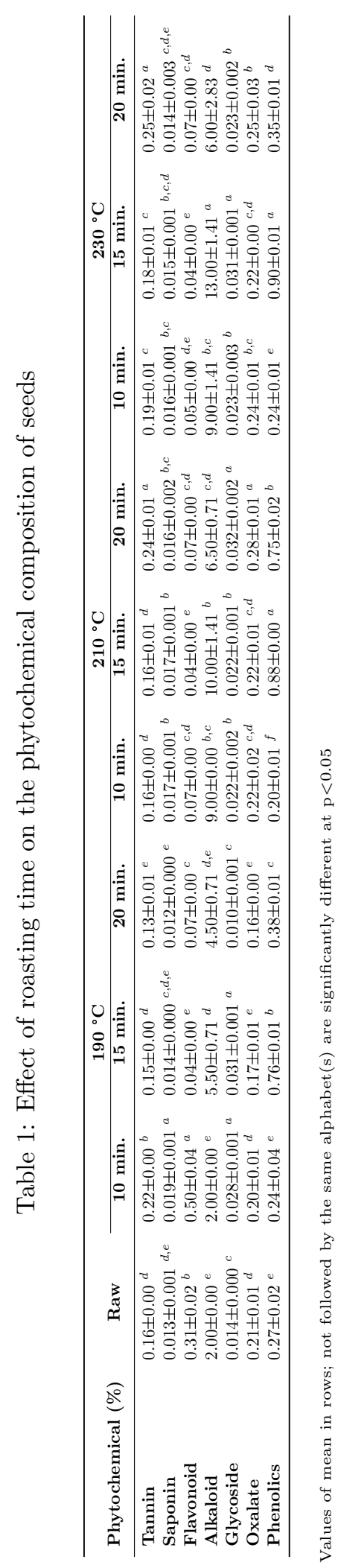

IJFS | October 2016 | Volume 5 | pages 203-211 
creasing temperature in samples roasted for 10 minutes but remained constant despite variations in temperature in samples roasted for 15 minutes. The same consistency was observed for samples roasted for 20 minutes. Meanwhile, samples roasted for 20 minutes had slightly higher values than those obtained for seeds roasted at 190, 210 and $230{ }^{\circ} \mathrm{C}$ for 15 minutes. It was observed that flavonoids were best retained in seeds roasted at $190{ }^{\circ} \mathrm{C}$ and 10 minutes and then next in all seeds roasted for the duration of $20 \mathrm{~min}-$ utes. Samples with the highest flavonoids content, i.e. $190{ }^{\circ} \mathrm{C} / 10$ mins, compared favourably with that of Richardia brasilensis (Edeoga et al., 2005) and Anchomanes difformis (Aliyu et al., 2008). While that of raw samples compared with Cleome rutidosperma (Edeoga et al., 2005) but was lower than that of Cassia occidentalis as reported in Kathirvel and Sujatha (2012). Alkaloids' content of seeds ranged from $2.00 \pm 0.00$ $\%$ in raw seeds and in roasted seeds at $190{ }^{\circ} \mathrm{C}$ for 10 minutes, to $13.00 \pm 1.41 \%$ in roasted seeds at $230{ }^{\circ} \mathrm{C}$ for 15 minutes. Alkaloids are phyto- constituents that intercalate with body deoxyribonucleic acid. No particular trend was observed with increasing duration of roasting, at each temperature, although most treatments for 10 minutes were significantly higher than in the raw sample except the treatment at $190{ }^{\circ} \mathrm{C}$. The alkaloid content increased from 10 to 15 minutes of treatment and then reduced upon further exposure to roasting (i.e. till 20 minutes). This may be a result of decomposition of other components of the seed; thus increasing the percentage content of alkaloids rather than a conversion of other components into alkaloids. The highest alkaloid content was found in the sample roasted at $230{ }^{\circ} \mathrm{C} / 15$ minutes. Results obtained for alkaloids' content are higher than those studied by Edeoga et al. (2005) and in Anchomanes difformis, Anisopus mannii and Pavetta crassipes (Aliyu et al., 2008) but much lower than those in raw Senna obtusifolia (Ingweye et al., 2010). All roasted samples had an increased percentage of glycoside content except $190{ }^{\circ} \mathrm{C} / 20 \mathrm{~min}$. Raw samples presented $0.014 \%$ glycosides and ranged between 0.010 and $0.032 \%$ in roasted samples, which implies that roasting does not extensively destroy the cyanogenic glycosides. It is notable that the average percentage of content of glyco- sides in seeds is relatively low and is found to be lower than that found in raw seeds of Senna obtusifolia (Ingweye et al., 2010), leaves' extract of Teleferia occidentalis (Ekpenyong, Akpan, \& Udoh, 2012) and Tanzanian locally available leaf and oil seed meals used as poultry feed ingredients (Mutayoba, Dierenfeld, Mercedes, Frances, \& Knight, 2011). Results of samples' oxalate content presented in Table 1 clearly show that cooking, including roasting, has a minute effect on the oxalate's content of food. The oxalate content of the raw sample was $0.21 \pm 0.01 \%$ while that of the roasted samples ranged between 0.16 $\pm 0.00 \%$ and $0.28 \pm 0.01 \%$ for roasting conditions of $190{ }^{\circ} \mathrm{C} / 20 \mathrm{~min}$ and $210{ }^{\circ} \mathrm{C} / 20$ minutes, respectively. Oxalate makes some mineral elements unavailable. Roasting at $190{ }^{\circ} \mathrm{C}$ for 10 , 15 and 20 minutes resulted in a $4.76 \%, 19.52 \%$ and $23.80 \%$ reduction in oxalate contents respectively (values of which were not significantly different from each other at $\mathrm{p}<0.05)$. Meanwhile, the oxalate content in samples roasted at $210{ }^{\circ} \mathrm{C}$ and $230 \mathrm{oC}$ were higher than that of raw samples. Akinmutimi (2006) recorded a $50 \%$ reduction in oxalate content between raw and processed Jack bean seed while Innocentia et al. (2014) recorded a $40-88 \%$ reduction between raw and roasted baobab. The percentage (\%) of oxalate contents of raw and roasted coffee senna seed were found to be lower than that of raw and roasted seeds of coffee-like baobab and other tropical crops studied by Proll et al. (1998), but higher than that in $100 \%$ maize-ogi flour (Enujiugha, 2006) and fluted pumpkin leaf extract (Nworgu et al., 2007). Phenolics have a strong antioxidant potential. The effect of roasting time-temperature combinations on sample phenolics ranged from $0.20 \%$ to $0.90 \%$. Treatment for 10 minutes generally resulted in a sample with a phenolics content lower than that in the raw sample by as much as a $6.86 \%$ reduction. Samples roasted for 15 and 20 minutes had higher phenolics content than raw samples. Seeds roasted for $15 \mathrm{~min}$ had a phenolics content higher than those roasted for $10 \mathrm{~min}$ and $20 \mathrm{~min}$, increasing with increased roasting temperature applied as in Figure 1. The highest phenolics content was found in samples with roasting conditions $230{ }^{\circ} \mathrm{C} / 15 \mathrm{~min}$ and the lowest in samples roasted at $210{ }^{\circ} \mathrm{C}$ for 10 mins. The phenolics content of raw and roasted Senna 
occidentalis were higher than those in E. heterophylla, R. bransilensis, S. dulcis, S. acuta, S. anthelmia, S.cyaenneusis and T. procumbeus all of which are medicinal plants (Edeoga et al., 2005), but lower than that in protein isolates of seed cake of Jathropha curcas (Makkar et al., 2008) as well as Anisopus mannii, Stachytarpheta angustifolia, Veronia blumeoides (Aliyu et al., 2008). The phenolic content of the ethanol extract of raw coffee senna seeds in this study $(0.27 \%)$ was comparable to that of the methanol extract of coffee senna seeds but lower than those of chloroform and petroleum ether extract as studied by Kathirvel and Sujatha (2012).

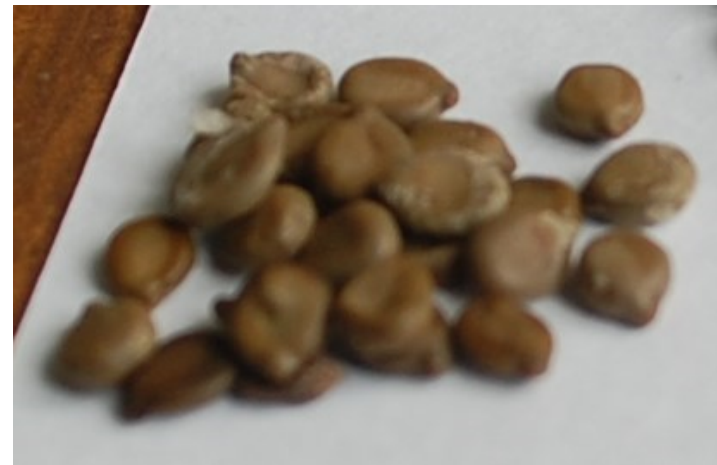

Figure 1: Seeds of S. occidentalis

\section{Conclusions}

This study has shown that the duration of exposure and the temperatures of roasting applied affect the seeds' phytochemical properties. While roasting did not totally eliminate the undesired phytochemicals (oxalate and tannin primarily), the resultant effect was that saponin and flavonoids contents reduced but phenolics, glycosides and alkaloids contents increased. The best phytochemical balance was observed in samples roasted at $210{ }^{\circ} \mathrm{C}$ for $15 \mathrm{~min}$. Other favorable conditions for roasting of coffee senna seeds were $210{ }^{\circ} \mathrm{C} / 10 \mathrm{~min}$ and $190{ }^{\circ} \mathrm{C} / 20 \mathrm{~min}$. The less favorable conditions were found to be the more severe roasting conditions of $230{ }^{\circ} \mathrm{C} / 20 \mathrm{~min}$ and $210{ }^{\circ} \mathrm{C} / 20$ min.

\section{References}

Abubakar, S. \& Sule, M. (2010). Effect of oral administration of aqueous extract of cassia occidentalis l. seeds on serum electrolytes concentration in rats. Bayero Journal of Pure and Applied Sciences, 3(1), 183-187.

Adamu, H. M., Ushie, O. A., \& Elisha, B. (2013). Chemical and nutrient analysis of raw and fermented seeds of cassia tora. Journal of Physical Science and Innovation Volume, 5(1), 125-138.

El-Adawy, T. A. \& Taha, K. M. (2001). Characteristics and composition of different seed oils and flours. Food Chemistry, 7/4(1), 4754. doi:10.1016/S0308-8146(00)00337-X

Akinmutimi, A. H. (2006). Nutritive value of raw and processed jack fruit seeds (artocarpus heterophyllus): chemical analysis. Agricultural Journal, 1(4), 266-271.

Aliyu, A. B., Musa, A. M., Oshanimi, J. A., Ibrahim, H. A., \& Oyewale, A. O. (2008). Phytochemical analyses and mineral elements composition of some medicinal plants of northern nigeria. Nigerian Journal of Pharmaceutical Sciences, 7(1), 119125.

Anonymous. (2012). Cassia seed (jue ming zi). Retrieved Aug. 23, 2012. Retrieved from http : / / acupuncturetoday. com / herbcentral/cassia_seed.php

Arogba, S. S. (1997). Physical, chemical and functional properties of nigerian mango (mangifera indica) kernel and its processed flour. Journal of the Science of Food and Agriculture, 73(3), 321-328.

Arunkumar, S. \& Muthuselvam, M. (2009). Analysis of phytochemical constituents and antimicrobial activities of aloe vera l. against clinical pathogens. World Journal of Agricultural Sciences, 5(5), 572-576.

Audu, S. S., Aremu, M. O., \& Lajide, L. (2013). Effects of processing on physicochemical and antinutritional properties of black turtle bean (phaseolus vulgaris l.) seeds flour. Oriental Journal of Chemistry, 29(3), 979989. doi:10.13005/ojc/290318

Belitz, H. D., Grosch, W., \& Schieberle, P. (2009). Food chemistry (4th). Springer, Verlag Berlin. 
Edeoga, H. O., Okwu, D. E., \& Mbaebie, B. O. (2005). Phytochemical constituents of some nigerian medicinal plants. African Journal of Biotechnology, 4 (7), 685-688.

Ekpenyong, C. E., Akpan, E. E., \& Udoh, N. S. (2012). Phytochemistry and toxicity studies of telfairia occidentalis aqueous leaves extract on liver biochemical indices in wistar rats. American Journal of Medicine and Medical Sciences, 2(5), 103-110.

Encarta. (2009). Substitute goods. 1993-2008 microsoft corporation.

Enujiugha, V. N. (2006). Supplementation of ogi, a maize-based infant weaning food, with african oil bean (pentaclethra macrophylla benth) seed. Journal of Food Agriculture and Environment, 4(2), 34-38.

Griffiths, D. W. \& Moseley, G. (1980). The effect of diets containing field beans of high or low polyphenolic content on the activity of digestive enzymes in the intestines of rats. Journal of the Science of Food and Agriculture, 31(3), 255-259. doi:10.1002/jsfa. 2740310307

Harborne, A. J. (1998). Phytochemical methods a guide to modern techniques of plant analysis. Springer Science \& Business Media.

Hussain, I., Ullah, R., Ullah, R., Khurram, M., Ullah, N., Baseer, A., ... Khan, N. (2011). Phytochemical analysis of selected medicinal plants. African Journal of Biotechnology, 10(38), 7487-7492.

Ingweye, J. N., Kalio, G. A., Ubua, J. A., \& Umoren, E. P. (2010). Nutritional evaluation of wild sicklepod (senna obtusifolia) seeds from obanliku, south-eastern nigeria. American Journal of Food Technology, 5(1), 1-12. doi:10.3923/ajft.2010.1.12

Innocentia, O. N., Ojotu, E. M., \& Emmanuel, A. (2014). Quality evaluation of coffee-like beverage from baobab (adansonia diditata) seed. Advance Journal of Food Science and Technology, 6(9), 1050-1055.

Kathirvel, A. \& Sujatha, V. (2012). Phytochemical studies of cassia occidentalis linn. flowers and seeds in various solvent extracts. International Journal of Pharmacognosy and Phytochemical Research, 3(4), 95-101.

Khokhar, S. \& Apenten, R. K. O. (2003). Antinutritional factors in food legumes and ef- fects of processing. The role of food, agriculture, forestry and fisheries in human nutrition, 4, 82-116. Retrieved from http:// www . eolss . net / ebooklib / ebookcontents / E5-01A-ThemeContents.pdf

Lewis, M. J. (2006). Thermal processing. Food processing handbook, 2, 33.

Makkar, H. P. S., Francis, G., \& Becker, K. (2008). Protein concentrate from jatropha curcas screw-pressed seed cake and toxic and antinutritional factors in protein concentrate. Journal of the Science of Food and Agriculture, 88(9), 1542-1548. doi:10. $1002 /$ jsfa.3248

Mensah, J. K., Okoli, R. I., Turay, A. A., \& OgieOdia, E. A. (2009). Phytochemical analysis of medicinal plants used for the management of hypertension by esan people of edo state, nigeria. Ethnobotanical leaflets, 13(10), 7. Retrieved from http://opensiuc. lib. siu . edu / cgi / viewcontent . cgi ? article= $1637 \%$ 5C\&context $=\mathrm{ebl}$

Molyneux, R. J., Lee, S. T., Gardner, D. R., Panter, K. E., \& James, L. F. (2007). Phytochemicals: the good, the bad and the ugly? Phytochemistry, 68(22-24), 29732985. doi:10.1016/j.phytochem.2007.09.004

Morrow, B. (1991). The rebirth of legumes. Food Technology, 45(9), 96-121.

Mutayoba, S. K., Dierenfeld, E., Mercedes, V. A., Frances, Y., \& Knight, C. D. (2011). Determination of chemical composition and antinutritive components for tanzanian locally available poultry feed ingredients. International Journal of Poultry Science, 10(5), 350-357.

Nworgu, F. C., Ogungbenro, S. A., \& Solesi, K. S. (2007). Performance and some blood chemistry indices of broiler chicken served fluted pumpkin (telfaria occidentalis) leaves extract supplement. AmericanEurasian Journal of Agriculture and Environmental Science, 2(1), 90-98.

Ogunlade, I., Ilugbiyin, A., \& Osasona, A. I. (2011). A comparative study of proximate composition, anti-nutrient composition and functional properties of pachira glabra and afzelia africana seed flours. African Journal of Food Science, 5(1), 32-35. 
Olapade, A. A., Ajayi, O. A., \& Ajayi, I. A. (2014). Physical and chemical properties of cassia sieberiana seeds. International Food Research Journal, 21(2), 767-772.

Olapade, A. A., Akinoso, R., \& Oduwaye, A. O. (2012). Changes in some physicochemical properties of cassia sieberiana seeds during roasting. Nigerian Food Journal, 30(1), 2634.

Oshoke, J. O. \& Akinyemi, A. O. (2015). Nutritional value of cassa occidentalis and its potential contribution to aquaculture feed. Pakistan Journal of Nutrition, 14(12), 924-930.

Proll, J., Petzke, K. J., Ezeagu, I. E., \& Metges, C. C. (1998). Low nutritional quality of unconventional tropical crop seeds in rats. Journal of Nutrition, 128(11), 2014-2022.

Sharma, A. \& Sehgal, S. (1992). Effect of domestic processing, cooking and germination on the trypsin-inhibitor activity and tannin content of faba bean (vicia-faba). Plant Foods for Human Nutrition, 42(2), 127-133. doi:10.1007/BF02196465

Sharma, B. L., Singh, D., Santosh Sharma, K., Hashmi, A., Singh, A., \& Bansal, A. (2013). Studies on some primary metabolite's extraction and quantification in different plant parts of selected cassia species. Asian Journal of Pharmaceutical and Clinical Research, 6(2), 309-314.

Shi, J., Arunasalam, K., Yeung, D., Kakuda, Y., Mittal, G., \& Jiang, Y. M. (2004). Saponins from edible legumes: chemistry, processing, and health benefits. Journal of Medicinal Food, 7(1), 67-78. doi:10.1089/ 109662004322984734

Shittu, O. B., Olabode, O. O., Omemu, A. M., Oluwalana, S., Adeniran, S., \& Akpan, I. (2014). Phytochemical and antimicrobial screening of spondias mombin, senna occidentalis and musa sapientum against vibrio cholerae o1. International Journal of Current Microbiology and Applied Sciences, 3(5), 948-961.

Teles, A. V. F. F., Fock, R. A., \& Gomiak, S. L. (2015). Effects of long-term administration of senna occidentalis seeds on the hematopoietic tissue of rats. Toxicon, 108, 73-79. doi:10.1016/j.toxicon.2015.09.042
Tyagi, S., Singh, G., Sharma, A., \& Aggarwal, G. (2010). Phytochemicals as candidate therapeutics: an overview. International Journal of Pharmaceutical Sciences Review and Research, 3(1), 53-55.

Vashishtha, V. M., John, T. J., \& Kumar, A. (2009). Clinical \& pathological features of acute toxicity due to cassia occidentalis in vertebrates. Indian Journal of Medical Research, 130(1), 23-30.

Veerachari, U. \& Bopaiah, A. K. (2012). Phytochemical investigation of the ethanol, methanol and ethyl acetate leaf extracts of six cassia species. International Research Journal of Pharmaceutical Sciences, 3(1), 34-39. 